\title{
Vegetation response to increased stocking rates in short- duration grazing
}

\author{
MICHAEL H. RALPHS, M. MORT KOTHMANN, AND CHARLES A. TAYLOR
}

\section{Abstract}

Short-duration grazing (SDG) has been purported to increase forage production and utilization compared to other grazing systems, and thus can sustain higher stocking rates. This study was designed to determine if standing crop could be maintained as stocking rates increased. Four stocking rate treatments ranging from the recommended rate for moderate continuous grazing to 2.5 times the recommended rate were applied in a simulated 8pasture SDG system. There was little change in frequency and composition of short-grasses over the study, but mid-grass frequency and composition both declined. Standing crop of all major forage classes declined as stocking rates increased. However, the rate of decline was less than proportional to the increase in stocking rate during the growing season. By fall, standing crop was inversely proportional to stocking rate, leading us to conclude that standing crop could not be maintained at the higher stocking rates. Low standing crop in the fall indicated a potential shortage of forage at the high stocking rates during the winter.

Key Words: standing crop, forage availability, frequency

Stocking rate is a critical factor affecting livestock production from rangelands. Under-stocking results in wasted forage and lower animal gain per unit area. Over-stocking results in excessive utilization of forage, deterioration of range condition, and lower gain per animal. Stocking rate directly affects frequency and intensity of defoliation (Hodgson and Olleronshaw 1969). As frequency and intensity of defoliation increase, production and vigor of plants decrease (Trlica 1977), palatable plants are replaced by less desirable species, and carrying capacity is reduced (Ellison 1960, Sarvis 1941, Lewis et al. 1956).

Two basic approaches have been used to minimize grazing damage to vegetation and soil: stock at moderate rates to avoid damage to desirable forage plants; and/or defer grazing to allow heavily utilized plants an opportunity to regain vigor (Martin and Whitfield 1973). Since it may not be possible to control the intensity of defoliation on individual plants in conventional grazing systems, management has generally reverted to periodic rests or deferment following grazing to allow recovery of desirable plants and to maintain desired species composition (Heady 1984).

Short-duration grazing (SDG) enhances the manager's ability to control the frequency of defoliation, and thus intensity of defoliation, of individual plants. SDG is a form of rotational grazing that utilizes high stock density for short periods in an attempt to uniformly graze a pasture. Livestock are rotated to a new pasture before regrowth occurs. Rotating through several pastures allows extended rest periods for plants to recover before livestock return (Kothmann 1980, 1984; Malechek and Dwyer 1983). SDG is purported to sustain higher stocking rates through increased forage production and utilization compared to other grazing systems (Savory 1978). The purpose of this study was to determine if herbage availability (as measured by standing crop), and species composition of the standing crop, could be maintained at increased stocking rates over a 5-year period under SDG.

\footnotetext{
Authors are range research scientist, USDA/Agr. Res. Serv., Poisonous Plant Research Laboratory, Logan, Utah, formerly graduate research assistant; professor, Range Science Dept., Texas A\&M Univ.; station director. Sonora Field Station, Texas Agr. Exp. Sta. Texas Agr. Exp. Sta. Journal Paper TA23662.

Manuscript accepted 24 May 1989.
}

\section{Materials and Methods}

The study was conducted at the Texas Agricultural Experiment Station near Sonora, Texas $\left(100^{\circ} 39^{\prime} \mathrm{W}, 30^{\circ} 34^{\prime} \mathrm{N}\right)$. Soils were Tarrant stony clay, 8 to $15 \mathrm{~cm}$ deep, and Tarrant silty clay, 15 to 25 $\mathrm{cm}$ deep (members of the clayey-skeletal, montmorillonitic, thermic family of Lithic Haplustalls). Range site classification was Low Stony Hills (SCS 1972). Vegetation on both soils was a mixed-grass prairie dominated by common curlymesquite [Hilaria belangeri (Steud.) Nash], Wright threeawn (Aristida wrightii Nash), purple threeawn ( $A$. purpurea Nutt), and sideoats grama [Bouteloua curtipendula (Michx) Torr.], with scattered motts of live oak (Quercus virginiana Mill.). Sacahuista (Nolina texana S. Wats.), a large grass-like plant of the Liliaceae family, was abundant on the shallow Tarrant stony clay soil and was considered the major nonherbaceous forage species.

An 8.5-ha pasture was subdivided into 2 blocks of 4 pastures each, roughly along the soil boundary. Four stocking rate treatments were randomly applied to the 4 pastures in each block. Herd size was constant and pasture sizes were varied to obtain the desired stocking rates. Stocking rates in block 2 were $20 \%$ greater than those in block 1 because there was a higher proportion of the deeper Tarrant silty clay soils which were more productive than the shallow Tarrant stony clay soil. Stocking rates were 1.38, 2.05, 2.64, and 3.46 AUM/ ha for block 1 , and 1.67, 2.52, 3.23, and 4.21 $\mathrm{AUM} /$ ha for block 2. These represented 1, 1.5, 2 and 2.5 times the recommended stocking rate for the respective sites (Merrill 1954). Two grazing herds, each consisting of two $317-\mathrm{kg}$ heifers and twelve $40-\mathrm{kg}$ yearling ewes ( $3 \mathrm{AU}$ ), were rotated through the pastures with the order of rotation randomly assigned at each grazing cycle. Pastures were alternately grazed 3 days and rested 51 days. To facilitate sampling and available labor, the grazing cycles of the 2 blocks were staggered. The cycle of block 1 began with the grazing period on 24 September 1980 . The cycle of block 2 began on 21 October. The grazing cycles continued through October 1985.

Standing crop of individual plant species was measured seasonally using the two-step sampling technique described by Anderson and Kothmann (1982). Vegetation was sampled before the first grazing period at the beginning of the study in September 1980, and at the end of the rest periods in May and July 1981, and in May, July and October 1985. Fifty plots were systematically located along randomly selected transects which ran the length of each pasture. Units of foliar cover were visually estimated using a 1 $\times 0.25-\mathrm{m}$ frame sectioned with a $6.25-\mathrm{cm}$ grid. Ten of the plots were clipped and species were separated and dried to determine weight per unit of cover. Standing crop was calculated as the product of weight per unit of cover, multiplied by the number of cover units of each plant species.

Standing crop data were analyzed by analysis of variance (SAS 1985) in a split-split plot design to determine differences between stocking rate treatments, years, and seasons within years (Table 1). In addition, the relationship between stocking rate (independent variable) and total standing crop (dependent variable) was described by linear regression for each season within years. Slopes of 
Table 1. Statistical model and mean squares of species standing crop sampled during spring, summer, and fall at the beginning and end of the 5 year study.

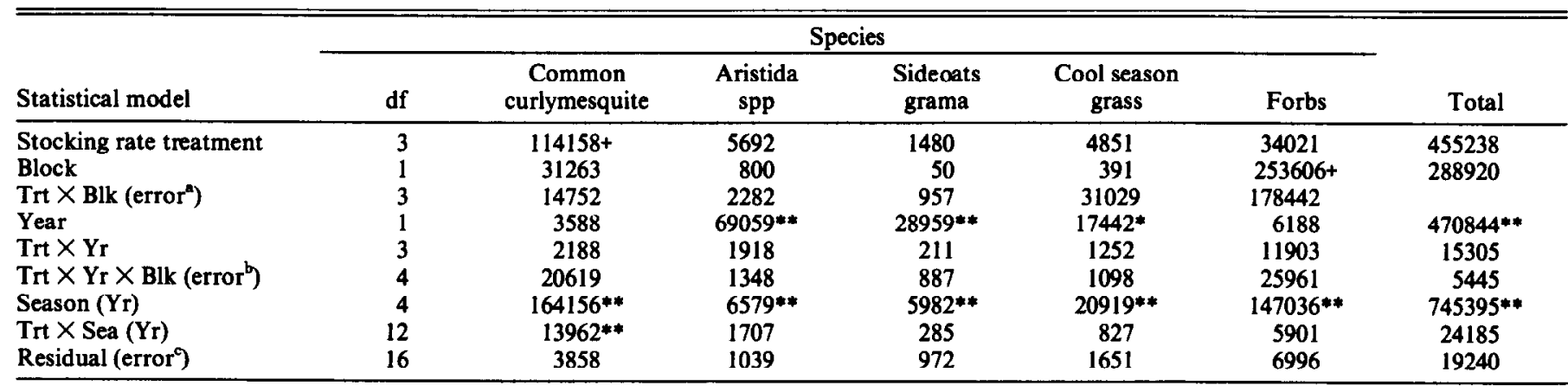

$+P<.10 ; * P<.05 ; * *<.01$

the seasonal regressions were compared to the initial regression of the standing crop in the fall of 1980 to determine differences $(P<.10)$.

Composition of species in the standing crop was calculated by dividing the standing crop of individual species or major forage classes by the total herbaceous standing crop. The percent of each species in the standing crop was calculated at the beginning of the study and near peak standing crop during the summers of 1981 and 1985. A split-plot ANOVA was used to compare treatments and dates.

Frequency of occurrence of the major warm-season grasses (curlymesquite, sideoats grama and threeawns) was calculated from the standing crop plots. Percentage change in frequency from the beginning of the study to the summer of 1985 was calculated and plotted as quadratic regressions on stocking rates. Frequency data from treatment 3 in block 2 were dropped from the regression due to sampling errors.

Sacahuista was most abundant on the shallow Tarrant stony clay loams; thus large differences in sacahuista density occurred between pastures and blocks. Standing crop was determined by counting the sacahuista plants in each pasture. Thirty to 50 plants in each pasture were randomly selected and the height and diameter measured and conical volume calculated. Fourteen plants of varying sizes were selected outside the study area; the volume was measured and foliage was harvested, dried, and weighed to determine weight per unit volume. The volume of the sampled plants was multiplied by the weight per unit volume to obtain the average weight per plant in each pasture. The number of plants was multiplied by the average weight per plant to obtain standing crop. Sacahuista standing crop was analyzed by analysis of covariance in a split-plot design to compare differences among stocking rate treatments and years. The initial number of sacahuista plants in each pasture was used as the covariate.

\section{Results and Discussion}

Figure 1 illustrates the changes in standing crop of important species and forage classes over the study. There were significant differences $(P<.01)$ in standing crop of all species and total standing crop between seasons (Table 1). Cool-season grasses and forbs generally achieved peak growth in the spring. In 1981, precipitation was high throughout the spring (Fig. 2) and supported continued growth of cool-season grasses into the summer. Standing crop of warm-season grasses peaked in the summer.

There were also significant differences $(P<.05)$ between years for all species and total standing crop, except for curlymesquite and forbs (Table 1). Change in standing crop over time is confounded with different amounts of precipitation received. Precipitation in 1980 was only $84 \%$ of average with poor seasonal distribution (Fig. 2). The low standing crop at the beginning of the study reflects the drought condition. Precipitation in 1981 was $30 \%$ above average and uniformly distributed throughout the spring and summer. Standing crop of most species peaked in the summer of 1981. Precipitation in 1985 was $90 \%$ of average; however, it was timely ( $18 \mathrm{~cm}$ fell in June and $10 \mathrm{~cm}$ fell in September) and ensured adequate soil moisture for growth during the summer and fall.

Total standing crop generally declined as stocking rate increased in spite of the favorable precipitation in 1981 and 1985 . The slope of the regression between standing crop and stocking rate in the fall of 1980 at the beginning of the study does not differ from $0(P=.18)$ (Fig. 3). The uniform low standing crop reflects the drought condition. The slope of the regression in the fall of 1985 is significant $(P=.03)$ and differs $(P<.05)$ from the slope of the regression in the fall 1980 (Fig. 3). There is little difference in standing crop from the beginning to the end of the study at the higher stocking rates. Heavy grazing pressure and high utilization kept the standing crop low even through precipitation was not limiting. The higher standing crop at the lighter stocking rates was due primarily to curlymesquite (see Fig. 1), which increased in response to the favorable precipitation (Thurow et al. 1988). The slope of regressions in the summers of 1981 and 1985 also differs from the regression at the

Table 2. Decrease in standing crop and the ratio of decreasing forage supply in relation to the increased demand from increasing stocking rates.

\begin{tabular}{|c|c|c|c|c|c|c|c|c|c|c|c|c|}
\hline \multirow{3}{*}{$\begin{array}{l}\text { Stocking rate } \\
\text { treatment }{ }^{1}\end{array}$} & \multicolumn{6}{|c|}{ Total herbaceous standing crop } & \multicolumn{6}{|c|}{ Ratio of available forage ${ }^{2}$} \\
\hline & \multirow{2}{*}{$\begin{array}{l}1980 \\
\text { Fall }\end{array}$} & \multicolumn{2}{|c|}{1981} & \multicolumn{3}{|c|}{1985} & \multirow{2}{*}{$\frac{1980}{\text { Fall }}$} & \multicolumn{2}{|c|}{1981} & \multicolumn{3}{|c|}{1985} \\
\hline & & Spring & Summer & Spring & Summer & Fall & & Spring & Summer & Spring & Summer & Fall \\
\hline $1.0 x$ & 530 & 1103 & $1620 \mathrm{~kg}$ & 877 & 1145 & 954 & 1.0 & 1.0 & 1.0 & 1.0 & 10 & 10 \\
\hline $1.5 \mathrm{x}$ & 435 & 1096 & 1416 & 578 & 955 & 706 & .82 & .99 & .87 & .66 & .83 & .74 \\
\hline $2.0 \mathrm{x}$ & 433 & 880 & 956 & 460 & 620 & 465 & .82 & .81 & .59 & .52 & .54 & .48 \\
\hline $2.5 \mathrm{x}$ & 410 & 796 & 1035 & 476 & 704 & 401 & .77 & .72 & .63 & .54 & .61 & .42 \\
\hline
\end{tabular}

'Increase in stocking rate compared to the recommended rate.

${ }^{2}$ Ratio to stocking rate treatment 1.0 standing crop. 

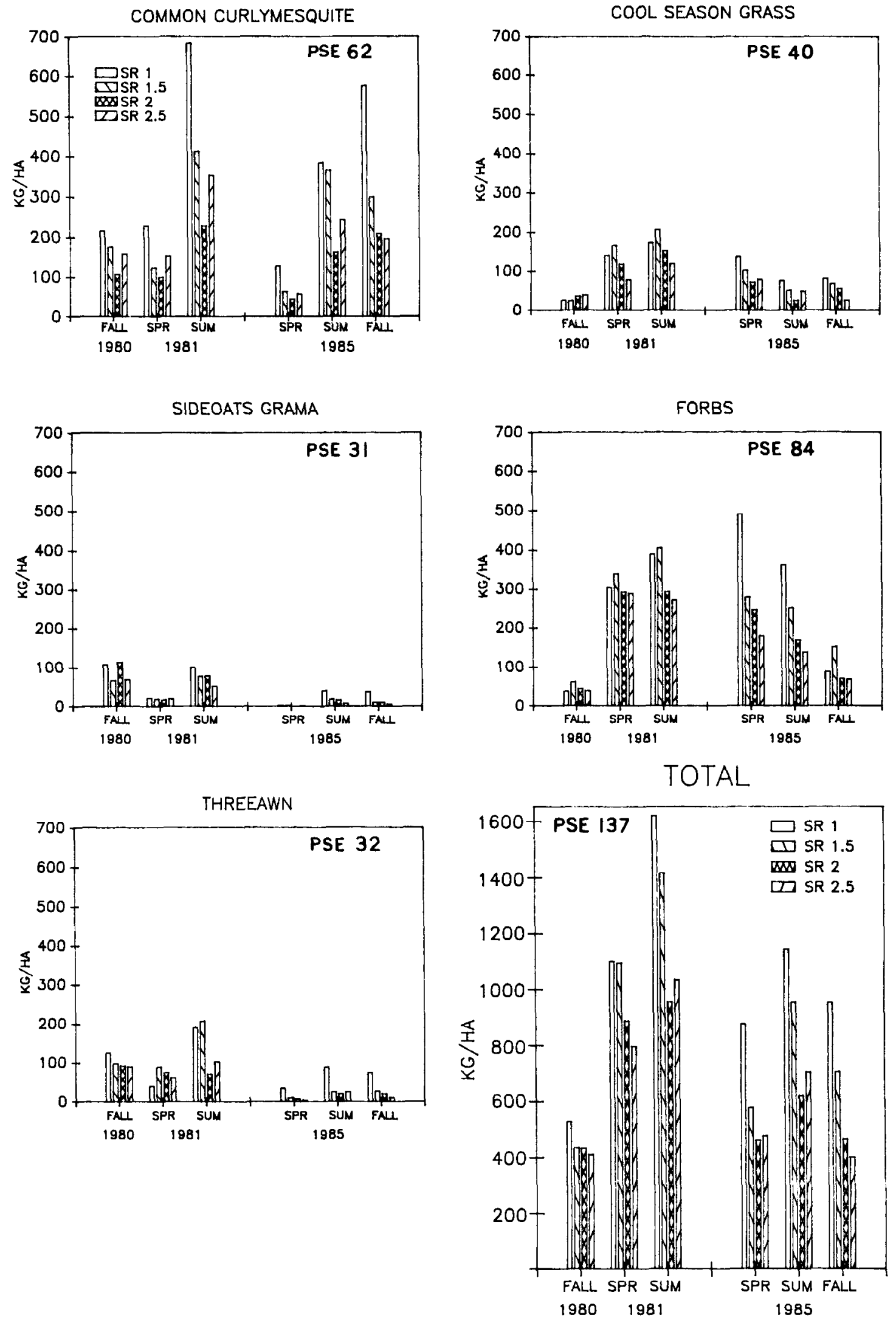

Fig. 1. Standing crop of species and forage groups at 4 stocking rate treatments at seasonal sampling periods during the first and last year of the 5-yr study. Pooled standard error (PSE) was calculated as the square root of the mean square error from the ANOVA. Standing crop was sampled at the end of the 51-d rest periods in the grazing cycles. 


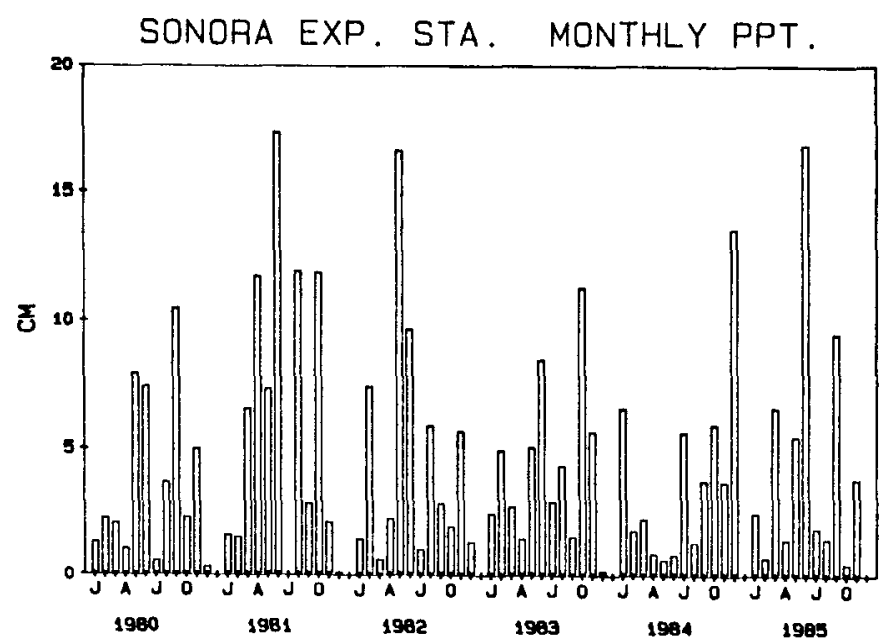

Fig. 2. Monthly precipitation at the Sonora Experiment Station during the study.

beginning of the study ( $P<.10$, data not shown). Standing crop of the $2.5 \mathrm{X}$ stocking rate treatment in block $2(4.21 \mathrm{AUM} / \mathrm{ha})$ appears to deviate from the trend of the other treatments (Fig. 3). This pasture was uniformly covered by the deep Tarrant silty clay soil and had the lowest cover of oak motts and sacahuista. The elevated standing crop in this pasture, both at the beginning and end of the study, was due to the higher growth potential of the site rather than the effects of the stocking rate treatment.

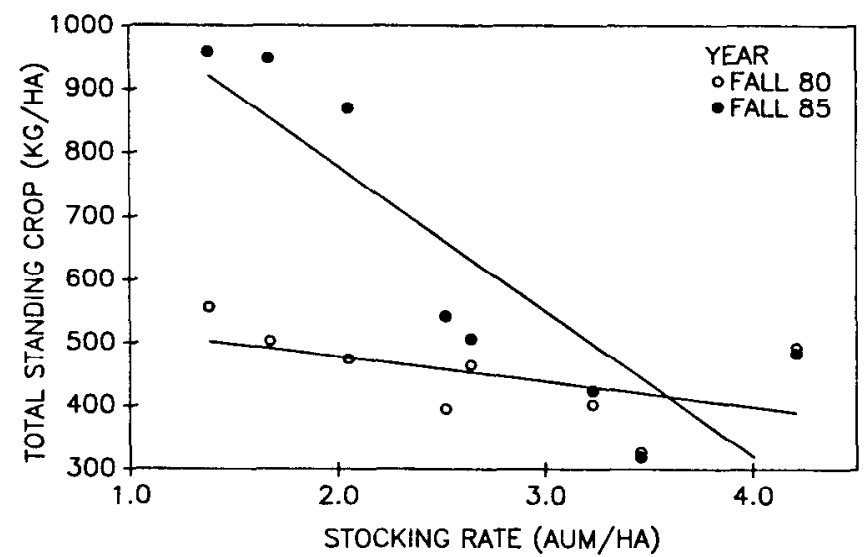

Fig. 3. Regression of total herbaceous standing crop in relation to increasing stocking rate in the fall 1980 at the beginning of the study and in the fall 1985 at the end of the study. The regression equation for fall 1980 is $y$ $=577-40 \times\left(R^{2}=0.27, P=0.18\right)$; the equation for fall 1985 is $y=1238-$ $299 x\left(R^{2}=0.74, P=0.03\right)$, where $y$ is total standing crop and $x$ is stocking rate.

Available forage, as expressed in total herbaceous standing crop, was not maintained as stocking rates increased in this SDG. However, the decline in standing crop was less than proportional to the increase in demand from increasing stocking rates during the spring and summer in 1981 and 1985 (Table 2). Growth during rest periods in the spring and summer compensated somewhat for removal of forage at the higher stocking rates. Pieper and Heitschmidt (1988) stated that SDG may be able to sustain higher stocking rates when conditions for regrowth are favorable. However, by the end of the growing season in the fall of 1985, standing crop was inversely proportional to the increase in stocking rate (Table 2). This means that going into the dormant winter season, there was less forage to meet the greater livestock demand at the higher stocking rates. Since these ranges are grazed yearlong, sufficient forage must be retained to last through the winter. Cattle and sheep exhausted the herbaceous forage in the higher stocking rate treatments and were forced to use low quality sacahuista during the dormant winter grazing season (Ralphs et al. 1986).

Sacahuista was abundant only on the Tarrant stony clay soil; thus, standing crop varied among the pastures independently of stocking rate or pasture size. The numbers of plants did not change, but the average mass of foliage per plant declined by $50 \%$ $(P=0.08)$ over the study. Standing crop ranged from 250 to 800 $\mathrm{kg} / \mathrm{ha}$ in 1980 and from 150 to $500 \mathrm{~kg} / \mathrm{ha}$ in 1985 .

Several studies have evaluated forage production in SDG compared to other grazing systems (Heitschmidt et al. 1987b, Kirby et al. 1986), and forage production at different stocking rates or stock densities within SDG (Brummer et al. 1988, Hart et al. 1988, Heitschmidt et al. 1987a). They concluded that SDG, or increasing stocking rates or stock densities within SDG, did not increase forage production. Higher stocking rates reduced standing crop due to the greater forage removal.

Stocking rate did not significantly influence species composition of the standing crop. However, species composition did change $(P<.01)$ from the beginning to the end of the study (Table 3 ). Mid-grasses declined from $43 \%$ of the standing crop at the beginning of the study, to $20 \%$ in the summer of 1981 , and finally

Table 3. Composition (\%) of functional species groups based on standing crop estimated at the end of 51 day rest periods, averaged across stocking rate treatments.

\begin{tabular}{|c|c|c|c|}
\hline Species & Fall 1980 & Summer 1981 & Summer 1985 \\
\hline & & $-\%-$ & \\
\hline Total short-grasses & $38^{\mathrm{a}}$ & $35^{\mathrm{a}}$ & $41^{\mathrm{a}}$ \\
\hline Total mid-grasses & $43^{a}$ & $20^{\mathrm{b}}$ & $10^{\mathrm{c}}$ \\
\hline Cool-season grasses & $7^{\mathrm{b}}$ & $13^{u}$ & $6^{\mathrm{b}}$ \\
\hline Forbs & $11^{\mathrm{b}}$ & $31^{\mathrm{a}}$ & $42^{a}$ \\
\hline
\end{tabular}

'Means of species within rows not followed by the same letter differ significantly $(P \leq 0.05)$.

dropped to only $10 \%$ in the summer of 1985 . Since composition was based on standing crop measured at the end of the 51-day rest periods, this represents regrowth during the rest period plus residual ungrazed forage from previous periods. The composition of the dominant bunchgrass species (threeawns and sideoats grama) each declined from about $20 \%$ of the standing crop at the beginning of the study to less than $4 \%$ in the summer of 1985 . These species were utilized heavily by both sheep and cattle during late spring/early summer while they were growing rapidly (Ralphs unpublished data). Composition of curlymesquite (the dominant shortgrass species) remained fairly constant throughout the study. Curlymesquite was utilized for a greater part of the year because of its dominance in the community. Composition of cool-season grasses increased in 1981, due to the abundant spring and early summer precipitation. Forbs increased throughout the study; however, bitterweed (Hymenosix odorata DC) an important poisonous plant, comprised $60 \%$ of the forb component in 1985 .

Increasing stocking rates did not change the relative frequency of curlymesquite from the beginning to the end of the study (Fig. 4). Frequency of sideoats grama and threeawns increased in the lightest stocking rate treatments but declined as stocking rates increased. However, we observed that close defoliation in all stocking rate treatments removed the old growth from large bunches of sideoats grama and other mid-grasses, resulting in their replacement by small individual tillers of low vigor. Butler and Briske (1988) also reported the breakup and fragmentation of large plants of little bluestem [Schizachyrium scoparium (Michx) Nash] in SDG stocked at 1.5 and 2 times the recommended rate. They 


\section{FREQUENCY}

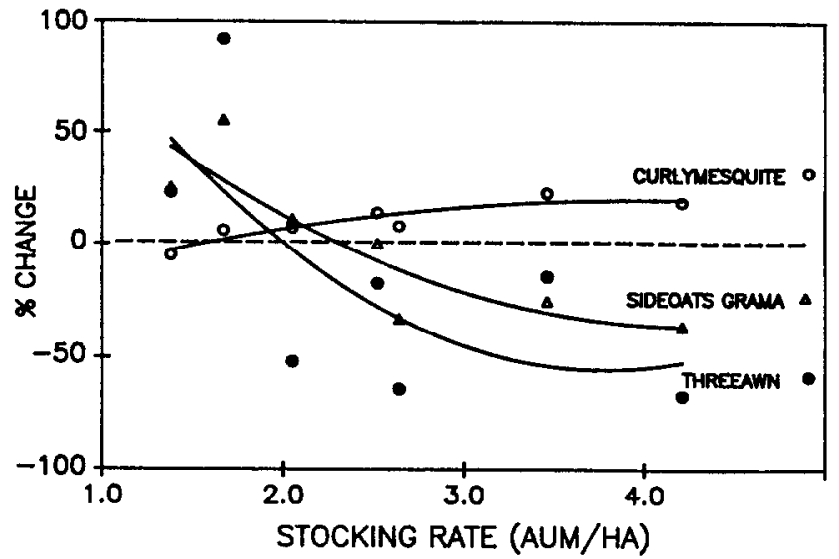

Fig. 4. Regression of the percent change in frequency of major warmseason species from the beginning (fall 1980) to the end of the study (summer 1985) at increasing stocking rates. Curlymesquite $y=68+25.7 x$ $-3 x^{2}\left(R^{2}=0.83, P=.02\right) ;$ sideonts grama $y=24083.6 x+9.9 x^{2}\left(R^{2}=0.76, P\right.$ $=.05)$; threeawns $y=297-134 x+17.7 x^{2}\left(R^{2}=0.45, P=0.30\right)$; where $y=\%$ change in frequency and $x$ is stocking rate ( $A U M / h a)$.

hypothesized that the smaller basal area would contribute to greater size-related mortality, resulting in the reduction of the bunchgrass component of the community. Reardon et al. (1974) reported that sideoats grama was harmed more by frequent defoliation similar to that experienced in SDG, than by more intense defoliation at longer intervals.

Because our sampling was conducted under grazed conditions, albeit at the end of the rest periods, our data do not conclusively demonstrate a change in species composition of the vegetation community. However, other studies in this location observed the shift from mid-grass, bunchgrass species to shortgrass species at heavy rates of stocking regardless of grazing system. In a concurrent watershed study, Thurow et al. (1988) reported that mid-grass cover declined $50 \%$ under heavily stocked SDG over a 6 -year period compared to moderate continuous grazing. They concluded that heavily stocked SDG changed the vegetative community from a mixed-grass community to a predominately shortgrass community resulting in more variable forage production, lowered infiltration, and increased erosion (Thurow et al. 1986). Smeins and Merrill (1988) reported similar results under continuous grazing of 3 stocking rates. They evaluated changes in basal area of grasses on permanent plots from 1948 to 1982 and concluded that continuous grazing at high stocking rates shifted the species composition to short-grasses, whereas in the absence of grazing, or with moderate grazing, there was a shift from short- to mid-grass species.

\section{Conclusions}

Standing crop of forage declined as stocking rates increased from the rate recommended under continuous grazing to 2.5 times that rate. During the growing season, the decline in standing crop was less than proportional to the increase in stocking rate. By fall, standing crop was inversely proportional to stocking rate, indicating a potential shortage of forage during the dormant winter season. This SDG was not able to sustain forage production, and probably not species composition at increased stocking rates. Forage responses to increasing stocking rates observed in this study under SDG are similar to those expected from continuous grazing at the same stocking rates.

\section{Literature Cited}

Anderson, D.M., and M.M. Kothmann. 1982. A two-step sampling technique for estimating standing crop of range vegetation. J. Range Manage. 35:675-677.
Brummer, J.E., R.L. Gillen, and F.T. McCollum. 1988. Herbage dynamics of tallgrass prairie under short duration grazing. J. Range Manage. 41:264-266.

Butler, J.L., and D.D. Briske. 1988. Population structure and tiller demography of the bunchgrass Schizachyrium scoparium in response to herbivory. Oikos 51:306-312.

Ellison, L. 1960. Influence of grazing on plant succession on rangelands. Bot. Rev. 26: 1-78.

Hart, R.H., M.J. Samuel, P.S. Test, and M.A. Smith. 1988. Cattle, vegetation and economic responses to grazing systems and grazing pressure. $J$. Range Manage. 41:282-286.

Heady, H.F. 1984. Concepts and principles underlying grazing systems, p. 885-902. In: Developing strategies for rangeland management. Nat. Acad. Sci. Westview Press, Boulder, Colo.

Heitschmidt, R.K., S.L. Dowhower, and J.W. Walker. 1987a. 14-vs.-42paddock rotational grazing: above ground biomass dynamics, forage production and harvest efficiency. J. Range Manage. 40:216-223.

Heitschmidt, R.K., S.L. Dowhower, and J.W. Walker. 1987b. Some effects of rotational grazing treatment on quantity and quality of available forage and amount of ground litter. J. Range Manage. 40:138-321.

Hodgson, J., and J.H. Olleronshaw. 1969. The frequency and severity of defoliation of individual tillers in set-swards. J. Brit. Grassl. Soc. 24:226-234.

Kirby, D.R., M.F. Pessin, and G.K. Clambey. 1986. Disappearance of forage under short duration and season long grazing. J. Range Manage. 39:496-512.

Kothmann, M.M. 1980. Evaluation of livestock needs in designing grazing systems for livestock, p. 78-90. In: D.C. Church (ed) Digestion physiology and nutrition of ruminants. 2nd ed. Vol. 3. Practical Nutrition. $O$ \& B Books, Corvallis, Ore.

Kothmann, M.M. 1984. Concepts and principles underlying grazing systems; discussant paper, p. 903-916. In: Developing strategies for rangeland management. Nat. Acad. Sci. Westview Pess, Boulder, Colo.

Lewis, J.K., G.M. Van Dyne, L.R. Albee, and F.W. Whetzal. 1956. Intensity of grazing-its effect on livestock and forage production. S. Dak. Agr. Exp. Sta. Bull. 459.

Malechek, J.C., and D.D. Dwyer. 1983. Short-duration grazing doubles your livestock? Utah Sci. 44:32-37.

Martin, S.C., and C.R. Whitfield (Co-charm.). 1973. Grazing systems for Arizona ranges. Arizona Interagency Range Committee. New Mexico Agr. Ext. Se. (Mimeo.).

Merrill, L.B. 1954. A variation of deferred rotation grazing for use under southwest range conditions. J. Range Manage. 7:152-154.

Pieper, R.D., and R.K. Heitschmidt. 1988. Is short duration grazing the answer? J. Soil and Water Conserv. 43:133-137.

Ralphs, M.H., M.M. Kothmann, and L.B. Merrill. 1986. Cattle and sheep diets under short duration grazing. J. Range Manage. 39:217-222.

Reardon, P.o., C.L. Leinweber, and L.B. Merrill. 1974. Response of sideoats grama to animal saliva and thiamine. J. Range Manage. 27:400-401.

SAS. 1985. SAS/STAT Guide for personal computers. 6 Ed. SAS Institute, Inc., Cary, N.C.

Sarvis, J.T. 1941. Grazing investigation on the northern Great Plains. North Dakota Agr. Exp. Sta. Bull. 308.

Savory, A. 1978. A holistic approach to range management using short duration grazing, p. 555-557. In: Proc. 1st Int. Rangeland Congress (ed. D.N. Hyder). Soc. for Range Manage., Denver, Colo.

SCS. 1972. Soil Conservation Service Field Office Technical Guide. Edwards Plateau, Texas.

Smeins, F.E., and L.B. Merrill. 1988. Long-term change in a semi-arid grassland, p. 101-114. In: B.B. Amos and F.R. Aehlbach (ed). Edwards Plateau vegetation-plant ecological studies in central Texas. Baylor Univ. Press. Waco, Texas.

Thurow, T.L., W.H. Blackburn, and C.A. Taylor Jr. 1986. Hydrologic characteristics of vegetation types as affected by livestock grazing systems, Edwards Plateau Texas. J. Range Manage. 39:505-509.

Thurow, T.L., W.H. Blackburn, and C.A. Taylor Jr. 1988. Some vegetation responses to selected livestock grazing strategies, Edwards Plateau, Texas. J. Range Manage. 41:108-114.

Trlica, M.J. 1977. Effects of frequency and intensity of defoliation on primary producers of arid and semi-arid rangelands, p. 27-55. In: The impact of herbivores on arid and semi-arid rangelands. Proc. 2nd U.S. Australia Rangeland Panel. Australian Rangeland Soc. Adelaide, Australia. 